Jurnal Health Sains: p-ISSN: 2723-4339 e-ISSN: 2548-1398

Vol. 2, No. 8, Agustus 2021

\title{
ANALISIS PROGRAM PENCEGAHAN DAN PENGENDALIAN INFEKSI DALAM PELAKSANAAN SURVEILANS HAI'S DI RUMAH SAKIT BHAYANGKARA TK II SARTIKA ASIH BANDUNG
}

\author{
Fitri Faridath, Ericka Aulia Rosyidah, Nurul Dwi Aryani \\ Politeknik Piksi Ganesha Bandung Jawa Barat, Indonesia \\ Email: fitrifaridath03@gmail.com, eiiaulia26@gmail.com, piyulnurul29@gmail.com
}

\begin{tabular}{ll}
\hline INFO ARTIKEL & ABSTRAK \\
\hline Diterima & Rumah sakit merupakan suatu institusi yang bergerak dibidang \\
5 Agustus 2021 & kesehatan dengan mengoptimalkan jasa pelayanan kesehatan sebagai \\
Direvisi & upaya meningkatkan derajat kesehatan bagi masyarakat. Penelitian ini \\
15 Agustus 2021 & berfokus pada analisa program pengendalian dan pencegahan infeksi \\
Disetujui & dalam pelaksanaan surveilans HAI's, tujuanya untuk melihat \\
25 Agustus 2021 & Permasalahan utama dalam infeksi rumah sakit yaitu mengacu pada \\
\hline Kata Kunci: & kemampuan rumah sakit tersebut dalam mencegah atau meminimalkan \\
pencegahan dan & terjadinya laju peningkatan infeksi. Metode Yang digunakan adalah \\
pengendalian & metode penelitian kualitatif deskriptif, dimana data hasil penelitian \\
infeksi; HAI's; & dideskripsikan dalam pengumpulan data melalui observasi dengan \\
surveilans & menggunakan metode phenomenological research, Data hasil dari \\
& observasi dipilih untuk kemudian dikategorikan dari data yang paling \\
& relevan. Setelah dilakukan penelitian, Maka Hasil yang didapatkan dari \\
& penelitian ini yaitu program PPI mengenai surveilans HAI's di Rumah \\
& Sakit Bhayangkara TK II Sartika Asih Bandung ini meliputi pelaporan \\
& infeksi nosokomial seperti Phlebitis, Dekubitus, ISK (infeksi saluran \\
& kemih), VAP (ventilator associated pneumonia) dan IDO (infeksi daerah \\
& operasi). Dan rumah sakit ini sudah melakukan pelaporan kejadian \\
& surveilans HAI's oleh Komite IPCN.
\end{tabular}

\section{ABSTRACT}

Hospital is an institution engaged in health by optimizing health services in an effort to improve the degree of health for the community. This study focuses on the analysis of infection control and prevention programs in the implementation of HAI's surveillance, the aim is to see the main problems in hospital infections, namely referring to the hospital's ability to prevent or minimize the rate of increase in infection, The method used is descriptive qualitative research method, where research data are described in data collection through observation using phenomenological research methods. Data from observations are selected and then categorized from the most relevant data. After doing the research, the results obtained from this research are the PPI program regarding HAI's surveillance at Bhayangkara TK II Sartika Asih Hospital Bandung includes reporting of nosocomial infections such

Keywords:

infection prevention and control; HAI's; surveillance as Phlebitis, Decubitus, UTI (urinary tract infection), VAP (ventilator associated pneumonia) and IDO (operation area infection). And this hospital has reported HAI's surveillance incidents by the IPCN Committee.

$\begin{array}{ll}\text { How to cite: } & \text { Faridath, F., Rosyidah, E. A., \& Aryani, N. D. (2021) Analisis Program Pencegahan dan } \\ & \text { Pengendalian Infeksi dalam Pelaksanaan Surveilans Hai's di Rumah Sakit Bhayangkara TK II } \\ & \text { Sartika Asih Bandung. Jurnal Health Sains 2(8). https://doi.org/10.46799/jhs.v2i8.248 } \\ \text { E-ISSN: } & 2723-6927 \\ \text { Published by: } & \text { Ridwan Institute }\end{array}$




\section{Pendahuluan}

Rumah sakit merupakan suatu institusi yang bergerak dibidang kesehatan dengan mengoptimalkan jasa pelayanan kesehatan sebagai upaya meningkatkan derajat kesehatan bagi masyarakat (Rikomah, 2017). Suatu rumah sakit dapat memberikan pelayanan yang optimal dan prima jika mampu meningkatkan kinerja sehingga terbentuk kualitas yang baik pada rumah sakit tersebut.

Di suatu rumah sakit, tidak jarang kita menemukan terjadinya infeksi baik pada pasien, petugas, pengunjung dan masyarakat sekitar rumah sakit. Hal ini dapat menyebabkan ketidakseimbangan dalam proses pelayanan di rumah sakit. Salah satu upaya yang dapat dilakukan yaitu dengan dikendalikan oleh tim komite Pencegahan dan Pengendalian Infeksi (PPI) (Salam, 2013).

Pencegahan dan pengendalian infeksi di rumah sakit dan fasilitas pelayanan kesehatan merupakan suatu upaya kegiatan untuk meminimalkan atau mencegah terjadinya infeksi pada pasien, petugas, pengunjung dan masyarakat sekitar rumah sakit (Umar, 2012). Salah satu program pencegahan dan pengendalian infeksi (PPI) adalah kegiatan surveilans, disamping adanya kegiatan lain seperti pendidikan dan latihan, kewaspadaan isolasi serta kegiatan surveilans infeksi difasilitas pelayanan kesehatan merupakan salah satu kegiatan yang penting dan luas dalam program pengendalian infeksi dan suatu hal yang harus dilakukan untuk mencapai keberhasilan dari program PPI (Ramayanti et al., 2019).

\section{World Health Organization}

mengungkapkan, infeksi nosocomial atau yang disebut healthcare associated infection (HAI's), adalah adverse effect (efek yang tidak dinginkan) yang paling sering terjadi di pelayanan kesehatan setiap tahunnya, yang mengarah kepada morbiditas, mortalitas, dan kerugian finansial di bidang kesehatan (Organization, 2018). Infeksi nosocomial mengakibatkan penggunaan sumber daya rumah sakit yang lebih besar dari biasanya. Dengan pencegahan yang baik, maka penggunaan sumber daya tersebut dapat diminimalkan (Organization, 2019).

Pada prinsipnya rumah sakit merupakan tempat untuk berobat dan mendapatkan perawatan medis bagi pasien rawat inap, namun seringkali orang yang berada di rumah sakit dapat beresiko tertular penyakit karena terpapar oleh sumber penyakit, seperti pada ruangan, peralatan serta lingkungan di rumah sakit (Sutarto, 2017). Infeksi yang terjadi atau didapat di rumah sakit, khususnya pada fasilitas kesehatan disebut dengan infeksi rumah sakit (IRS). Maka dengan kondisi tersebut rumah sakit dapat berupaya untuk mengatasi peningkatan infeksi di rumah sakit dengan melakukan kegiatan surveilans infeksi rumah sakit.

Surveilans Infeksi Rumah Sakit adalah suatu proses yang dinamis, sistematis, terusmenerus dalam pengumpulan data, identifikasi, analisis dan interprestasi dari data kesehatan yang penting pada suatu populasi spesifik yang didiseminasikan secara berkala kepada pihak-pihak yang memerlukan untuk digunakan dalam perencanaan, penerapan dan evaluasi suatu tindakan yang berhubungan dengan kesehatan (Wardoyo et al., 2018). Surveilans diperlukan dalam hal ini guna meminimalkan bahkan menghentikan laju terjadinya infeksi pada pasien maupun petugas kesehatan. Proses ini memerlukan beberapa kegiatan proaktif untuk mempercepat penurunan laju infeksi yang mungkin terjadi (Amirah \& Safrizal Ahmaruddin, 2020).

Setiap rumah sakit dapat menentukan dan merencanakan kegiatan surveilans sesuai dengan kebutuhan serta kondisi masingmasing dari rumah sakit tersebut. Karena tidak semua rumah sakit memiliki kondisi yang sama dalam hal infeksi rumah sakit ini, maka kegiatan program surveilans ini berbeda satu sama lain (Purba et al., 2018). Fasilitas 
Analisis Program Pencegahan dan Pengendalian Infeksi dalam Pelaksanaan Surveilans Hai's di Rumah Sakit Bhayangkara TK II Sartika Asih Bandung

yang disediakan oleh rumah sakit tentunya harus memadai sebagai penunjang kegiatankegiatan yang berhubungan dengan infeksi ini. Dengan adanya kegiatan surveilans pada program pencegahan dan pengendalian infeksi di rumah sakit (PPIRS) diharapkan dapat menurunkan laju infeksi (Adhiwijaya, 2017).

Keselamatan pasien merupakan indikator utama dalam pelayanan kesehatan, yang menjadi acuan bagi rumah sakit dalam menghasilkan kualitas pelayanan yang lebih baik dan optimal sehingga mampu mengurangi insiden bagi pasien. Dalam sasaran keselamatan pasien yang menjadi faktor utama yaitu penanganan intensif bagi pasien yang memerlukan tindakan darurat, sedangkan pasien yang masih mampu untuk menunggu dapat diberikan penanganan yang sesuai untuk pemenuhan kebutuhan pasien selama di rumah sakit (Ismainar, 2015).

Permasalahan utama dalam infeksi rumah sakit yaitu mengacu pada kemampuan rumah sakit tersebut dalam mencegah atau meminimalkan terjadinya laju peningkatan infeksi. Dengan meningkatnya infeksi, maka akan terjadi peningkatan masa tinggal pasien di rumah sakit, yang akan mengakibatkan peningkatan yang signifikan dalam biaya pengobatan. Karena di setiap rumah sakit memiliki prosedur dalam upaya pencegahan yang berbeda (Madjid \& Wibowo, 2019).

\section{Metode Penelitian}

Penelitian ini menggunakan metode penelitian kualitatif deskriptif, dimana data hasil penelitian dideskripsikan dalam pengumpulan data melalui observasi dengan menggunakan metode phenomenological research, yaitu penelitian kualitatif dimana peneliti melakukan pengumpulan data dengan observasi partisipan untuk mengetahui fenomena esensial partisipan dalam pengalaman hidupnya. Penelitian ini mendeskripsikan data dari program PPI surveilans HAI's di Rumah Sakit Bhayangkara TK II Sartika Asih Bandung. Data hasil dari observasi dipilih untuk kemudian dikategorikan dari data yang paling relevan. Pendekatan yang digunakan adalah studi kasus pada infeksi nosokomial yang terjadi di rumah sakit seperti Phlebitis, Dekubitus, ISK, VAP dan IDO. Subyek dalam penelitian adalah petugas IPCN pada bagian PPI di Rumah Sakit Bhayangkara TK II Sartika Asih Bandung. Obyek penelitian ini adalah program PPI dalam pelaksanaan surveilans HAI's.

\section{Hasil dan Pembahasan}

\section{A. Hasil Penelitian}

Setelah dilakukan penelitian, maka hasil yang didapatkan dari penelitian ini yaitu: Program PPI mengenai surveilans HAI's di Rumah Sakit Bhayangkara TK II Sartika Asih Bandung ini meliputi pelaporan infeksi nosokomial seperti Phlebitis, Dekubitus, ISK (infeksi saluran kemih), VAP (ventilator associated pneumonia) dan IDO (infeksi daerah operasi).

Berikut data hasil pelaporan yang di peroleh dari bagian PPI di Rumah Sakit Bhayangkara TK II Sartika Asih Bandung: 
Tabel 1

Laporan Infeksi Bulan Januari 2021

\begin{tabular}{|c|c|c|c|c|c|c|c|c|c|}
\hline \multirow[t]{2}{*}{ No } & \multirow[b]{2}{*}{ Ruangan } & \multirow[b]{2}{*}{$\begin{array}{c}\text { Jumlah } \\
\text { Pasien }\end{array}$} & \multicolumn{5}{|c|}{ Jumlah Pasien Yang Infeksi } & \multirow[t]{2}{*}{ Ket } & \multirow[t]{2}{*}{ Harwat } \\
\hline & & & Decub & Phlebitis & Isk & Vap & Ido & & \\
\hline 1 & $\mathrm{Llb}$ & 169 & 0 & 2 & 0 & 0 & 0 & $4,1 \%$ o & 484 \\
\hline 2 & Fajar & 313 & 0 & 4 & 0 & 0 & 0 & $4,5 \%$ & 870 \\
\hline 3 & Obgyn & 125 & 0 & 1 & 0 & 0 & 0 & $4,8 \%$ o & 205 \\
\hline 4 & Perina & 75 & 0 & 0 & 0 & 0 & 0 & 0 & 213 \\
\hline 5 & Icu & 41 & 1 & 0 & 0 & 1 & 0 & $5,8 \%$ & 171 \\
\hline 6 & Bhayangkara & 117 & 0 & 4 & 0 & 0 & 0 & $9,4 \%$ о & 424 \\
\hline 7 & Lodaya 1 & 162 & 0 & 5 & 0 & 0 & 0 & $4,3 \%$ & 461 \\
\hline 7 & Lodaya 2,3 & 121 & 0 & 2 & 0 & 0 & 0 & $5,4 \%$ o & 369 \\
\hline 8 & Sartika & 153 & 0 & 5 & 0 & 0 & 0 & $11,4 \% 0$ & 437 \\
\hline \multirow[t]{2}{*}{9} & Anak & 165 & 0 & 4 & 0 & 0 & 0 & $7,2 \%$ & 550 \\
\hline & JUMLAH & 1441 & 1 & 26 & 0 & 0 & 0 & & \\
\hline
\end{tabular}

Keterangan:

Infeksi nosokomnial diduga:

$\begin{array}{ll}\text { Decubitus } & 0 \% \\ \text { Phlebitis } & 26 \% \text { o } \\ \text { ISK } & 0 \% \text { o } \\ \text { VAP } & 0 \% \text { o } \\ \text { IDO } & 0 \%\end{array}$

Dari data tabek 1, menunjukkan bahwa laporan infeksi HAI's bulan Januari 2021 terdapat total 1441 pasien di semua ruangan dan telah terjadi infeksi Decubitus di ruangan ICU terdapat 1 pasien dari total 41 pasien, sedangkan pada ruangan LLB, Fajar, Obgyn, Perinatologi, Bhayangkara, Lodaya 1, Lodaya 2,3, Sartika, dan Anak tidak terdapat adanya infeksi Decubitus. Pada infeksi Phlebitis di ruangan LLB terdapat 2 pasien dari total 169 pasien, di ruangan Fajar terdapat 4 pasien dari total 313 pasien, di ruangan Obgyn terdapat 1 pasien dari total 125 pasien, di ruangan Perinatologi tidak terdapat infeksi, di ruangan ICU tidak terdapat infeksi, di ruangan Bhayangkara terdapat 4 pasien dari total 117 pasien, di ruangan Lodaya 1 terdapat 5 pasien dari total 162 pasien, di ruangan Lodaya 2,3 terdapat 2 pasien dari total 121 pasien, di ruangan Sartika terdapat 5 pasien dari total 153 pasien, dan di ruangan Anak terdapat 4 pasien dari total 165 pasien, dan total infeksi Phlebitis sebanyak 26 pasien terinfeksi. Pada infeksi VAP (ventilator associated pneumonia) terdapat 1 pasien di ruangan ICU, sedangkan pada ruangan LLB, Fajar, Obgyn, Perinatologi, Bhayangkara, Lodaya 1, Lodaya 2,3, Sartika, dan Anak tidak terdapat adanya infeksi VAP. Kemudian pada infeksi ISK (infeksi saluran kemih) dan IDO (infeksi daerah operasi) tidak terdapat adanya infeksi nosokomial di semua ruangan.

Infeksi nosokomial yang terjadi pada bulan januari 2021 ini menyebabkan terjadinya infeksi pada beberapa pasien. Infeksi yang banyak terjadi yaitu infeksi phlebitis sebanyak 26 jumlah pasien yang terinfeksi. Persentase dari laporan infeksi HAI's bulan januari 2021 ini menunjukkan infeksi Decubitus sebanyak $0 \%$, infeksi Phlebitis sebanyak 26\%, infeksi ISK sebanyak $0 \%$, infeksi VAP sebanyak 0 $\%$, dan infeksi IDO sebanyak $0 \%$. 
Analisis Program Pencegahan dan Pengendalian Infeksi dalam Pelaksanaan Surveilans Hai's di Rumah Sakit Bhayangkara TK II Sartika Asih Bandung

Tabel 2

Laporan Infeksi Bulan Februari 2021

\begin{tabular}{|c|c|c|c|c|c|c|c|c|c|}
\hline \multirow[t]{2}{*}{ No } & \multirow[b]{2}{*}{ Ruangan } & \multirow[b]{2}{*}{$\begin{array}{l}\text { Jumlah } \\
\text { Pasien }\end{array}$} & \multicolumn{5}{|c|}{ Jumlah Pasien Yang Infeksi } & \multirow[t]{2}{*}{ Ket } & \multirow[t]{2}{*}{ Harwat } \\
\hline & & & Decub & Phlebitis & Isk & Vap & Ido & & \\
\hline 1 & Llb & 162 & 0 & 1 & 0 & 0 & 0 & $2,3 \%$ & 421 \\
\hline 2 & Fajar & 305 & 0 & 3 & 0 & 0 & 0 & $3,3 \%$ & 892 \\
\hline 3 & Obgyn & 120 & 0 & 0 & 0 & 0 & 0 & 0 & 230 \\
\hline 4 & Perina & 84 & 0 & 0 & 0 & 0 & 0 & 0 & 284 \\
\hline 5 & Icu & 28 & 0 & 0 & 0 & 0 & 0 & 0 & 97 \\
\hline 6 & Bhayangkara & 90 & 0 & 4 & 0 & 0 & 0 & $13 \%$ & 306 \\
\hline 7 & Lodaya 1 & 147 & 0 & 3 & 0 & 0 & 0 & $7,6 \%$ & 394 \\
\hline 7 & Lodaya 2,3 & 100 & 0 & 2 & 0 & 0 & 0 & $6,6 \%$ & 301 \\
\hline 8 & Sartika & 154 & 0 & 4 & 0 & 0 & 0 & $13 \%$ & 306 \\
\hline \multirow[t]{2}{*}{9} & Anak & 119 & 0 & 5 & 0 & 0 & 0 & $11,6 \%$ & 428 \\
\hline & Jumlah & 1309 & 0 & 22 & 0 & 0 & 0 & $57,4 \%$ & \\
\hline
\end{tabular}

Keterangan:

Infeksi nosokomnial diduga:

Decubitus $\quad 0 \%$

Phlebitis $\quad 57,4 \%$

ISK $\quad 0.00 \%$

VAP $\quad 0 \%$

IDO $\quad 0 \%$

Dari data diatas menunjukkan

bahwa laporan infeksi HAI's bulan Februari 2021 terdapat total 1309 pasien di semua ruangan dan telah terjadi infeksi Phlebitis di ruangan LLB terdapat 1 pasien dari total 162 pasien, di ruangan Fajar terdapat 3 pasien dari total 305 pasien, di ruangan Obgyn tidak terdapat infeksi, di ruangan Perinatologi tidak terdapat infeksi, di ruangan ICU tidak terdapat infeksi, di ruangan Bhayangkara terdapat 4 pasien dari toal 90 pasien, di ruangan Lodaya 1 terdapat 3 pasien dari total 147 pasien, di ruangan Lodaya 2,3 terdapat 2 pasien dari total 100 pasien, di ruangan
Sartika terdapat 4 pasien dari total 154 pasien, dan di ruangan Anak terdapat 5 pasien dari total 119 pasien, dan total infeksi Phlebitis sebanyak 22 pasien terinfeksi. Kemudian pada infeksi Decubitus, ISK (infeksi saluran kemih), VAP (ventilator associated pneumonia), dan IDO (infeksi daerah operasi) tidak terdapat adanya infeksi nosokomial di semua ruangan.

Infeksi nosokomial yang terjadi pada bulan februari 2021 ini menyebabkan terjadinya infeksi pada beberapa pasien. Infeksi yang banyak terjadi yaitu infeksi phlebitis sebanyak 22 jumlah pasien yang terinfeksi. Persentase dari laporan infeksi HAI's bulan februari 2021 ini menunjukkan infeksi Decubitus sebanyak 0 \%o, infeksi Phlebitis sebanyak 57,4\%, infeksi ISK sebanyak $0 \%$, infeksi VAP sebanyak $0 \%$, dan infeksi IDO sebanyak $0 \%$. 
Tabel 3

Laporan Infeksi Bulan Maret 2021

\begin{tabular}{|c|c|c|c|c|c|c|c|c|c|}
\hline \multirow[t]{2}{*}{ No } & \multirow[b]{2}{*}{ Ruangan } & \multirow[b]{2}{*}{ Jumlah Pasien } & \multicolumn{5}{|c|}{ Jumlah Pasien Yang Infeksi } & \multirow[t]{2}{*}{ Ket } & \multirow[t]{2}{*}{ Harwa } \\
\hline & & & Decub & Phlebitis & Isk & Vap & Ido & & \\
\hline & $\mathrm{Llb}$ & 149 & 0 & 1 & 0 & 0 & 0 & $2,3 \% 0$ & 421 \\
\hline & Fajar & 285 & 0 & 4 & 0 & 0 & 0 & $4,9 \%$ & 806 \\
\hline 3 & Obgyn & 103 & 0 & 0 & 0 & 0 & 0 & 0 & 184 \\
\hline 4 & Perinatologi & 77 & 0 & 1 & 0 & 0 & 0 & $3,7 \%$ & 268 \\
\hline & Icu & 37 & 0 & 0 & 0 & 0 & 0 & 0 & 143 \\
\hline 6 & Bhayangkara & 114 & 0 & 4 & 0 & 0 & 0 & 0 & 373 \\
\hline & Lodaya 1 & 124 & 0 & 4 & 0 & 0 & 0 & $10 \%$ & 333 \\
\hline & Lodaya 2,3 & 79 & 0 & 3 & 0 & 0 & 0 & $12 \%$ & 250 \\
\hline & Sartika & 114 & 0 & 4 & 0 & 0 & 0 & 0 & 354 \\
\hline & Anak & 140 & 0 & 7 & 0 & 0 & 0 & $12,5 \%$ & 556 \\
\hline & JUMLAH & 1222 & 0 & 28 & 0 & 0 & 0 & $45,4 \% c$ & 3688 \\
\hline
\end{tabular}

Keterangan:

Infeksi nosokomnial diduga:

Decubitus $\quad 0 \%$

Phlebitis $\quad 7,5 \%$

ISK $\quad 0.00 \%$

VAP $\quad 0 \%$

IDO $\quad 0 \%$

Dari data diatas menunjukkan bahwa laporan HAI's bulan Maret 2021 terdapat total 1222 pasien di semua ruangan dan telah terjadi infeksi Phlebitis di ruangan LLB terdapat 1 pasien dari total 149 pasien, di ruangan Fajar terdapat 4 pasien dari total 285 pasien, di ruangan Obgyn tidak terdapat infeksi, di ruangan Perinatologi terdapat 1 pasien dari total 103 pasien, di ruangan ICU tidak terdapat infeksi, di ruangan Bhayangkara terdapat 4 pasien dari total 114 pasien, di ruangan Lodaya 1 terdapat 4 pasien dari total 124 pasien, di ruangan Lodaya 2,3 terdapat 3 pasien dari total 79 pasien, di ruangan Sartika terdapat 4 pasien dari total 114 pasien, dan di ruangan Anak terdapat 7 pasien dari total 140 pasien dan total infeksi Phlebitis sebanyaj 28 pasien terinfeksi. Kemudian pada infeksi Decubitus, ISK (infeksi saluran kemih), VAP (ventilator associated pneumonia), dan IDO (infeksi daerah operasi) tidak terdapat adanya infeksi nosokomial di semua ruangan.

Infeksi nosokomial yang terjadi pada bulan maret 2021 ini menyebabkan terjadinya infeksi pada beberapa pasien. Infeksi yang banyak terjadi yaitu infeksi phlebitis sebanyak 28 jumlah pasien yang terinfeksi. Persentase dari laporan infeksi HAI's bulan maret 2021 ini menunjukkan infeksi Decubitus sebanyak $0 \%$, infeksi Phlebitis sebanyak 7,5\%o, infeksi ISK sebanyak $0 \%$, infeksi VAP sebanyak 0 $\%$, dan infeksi IDO sebanyak $0 \%$. 
Analisis Program Pencegahan dan Pengendalian Infeksi dalam Pelaksanaan Surveilans Hai's di Rumah Sakit Bhayangkara TK II Sartika Asih Bandung

Tabel 4

infeksi HAI's dalam triwulan 1 (Januari, Februari dan Maret)

\begin{tabular}{lccccc}
\hline & Phlebitis & Decubitus & IDO & VAP & ISK \\
\hline Llb & 2,3 & 0 & 0 & 0 & 0 \\
\hline Fajar & 3,3 & 0 & 0 & 0 & 0 \\
\hline Obgyn & 0 & 0 & 0 & 0 & 0 \\
\hline Perinatologi & 0 & 0 & 0 & 0 & 0 \\
\hline Icu & 0 & 0 & 0 & 0 & 0 \\
\hline Bhayangkara & 13 & 0 & 0 & 0 & 0 \\
\hline Lodaya 1 & 7,6 & 0 & 0 & 0 & 0 \\
\hline Lodaya 2,3 & 6,6 & 0 & 0 & 0 & 0 \\
\hline Sartika & 13 & 0 & 0 & 0 & 0 \\
\hline Anak & 11,6 & 0 & 0 & 0 & 0 \\
\hline
\end{tabular}

Pada data Tabek 4 menunjukkan bahwa laporan infeksi HAI's dalam triwulan 1 (Januari, Februari dan Maret) terjadi infeksi phlebitis pada ruangan LLB sebanyak 2, 3, ruangan Fajar sebanyak 3,3, ruangan Obgyn tidak terjadi infeksi phlebitis, ruangan Perinatologi tidak terjadi infeksi phlebitis, ruangan ICU tidak terjadi infeksi phlebitis, ruangan Bhayangkara sebanyak 13, ruangan Lodaya 1 sebanyak 7,6, ruangan Lodaya 2 dan 3 sebanyak 6,6, ruangan Sartika sebanyak 13, dan ruangan Anak sebanyak 11,6. Sedangkan pada infeksi Dekubitus, IDO, VAP dan ISK tidak terdapat adanya infeksi pada semua ruangan di Rumah Sakit Bhayangkara TK II Sartika Asih Bandung.

\section{B. Pembahasan}

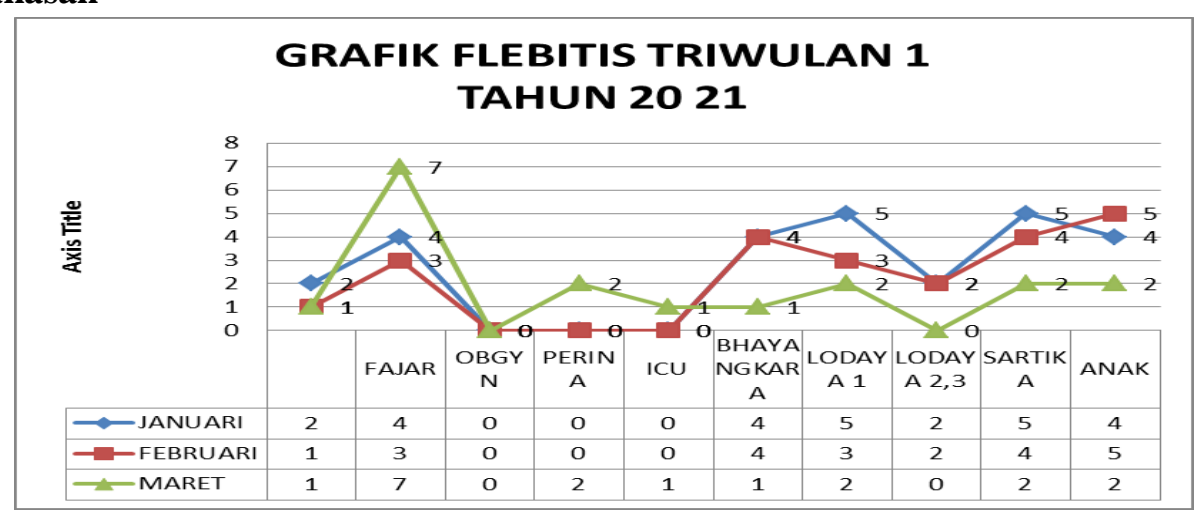

Grafik diatas menunjukan ada peningkatan angka kejadian flebitis pada bulan maret dan angka yang paling tinggi yaitu sebanyak $7 \%$ terjadi di ruang Fajar, dan pada bulan Januari angka yang paling tinggi terjadi di ruangan Lodaya 2,3 serta Ruangan Sartika yaitu sebanyak 5\%, namun mengalami penurunan kembali pada bulan Februari. Data diatas menunjukan tidak melebihi ketentuan yang dimiliki rumah sakit yaitu $25 \%$.

Beberapa rencana dan tindak lanjut yang telah dilaksanakan oleh Komite PPI, yaitu sebagai berikut:

1. Memberikan Reward dan punishment untuk kepatuhan cuci tangan.

2. Melakukan Penerapan teknik aseptik pada saat pemasangan kanula vena. 
Analisis Program Pencegahan dan Pengendalian Infeksi dalam Pelaksanaan Surveilans Hai's di Rumah Sakit Bhayangkara Tk Ii Sartika Asih Bandung

3. Meningkatkan kepatuhan cuci tangan dengan cara monitoring rutin.
4. Melakukan Sosialisasi kembali prosedur pemasangan infus sesuai SPO

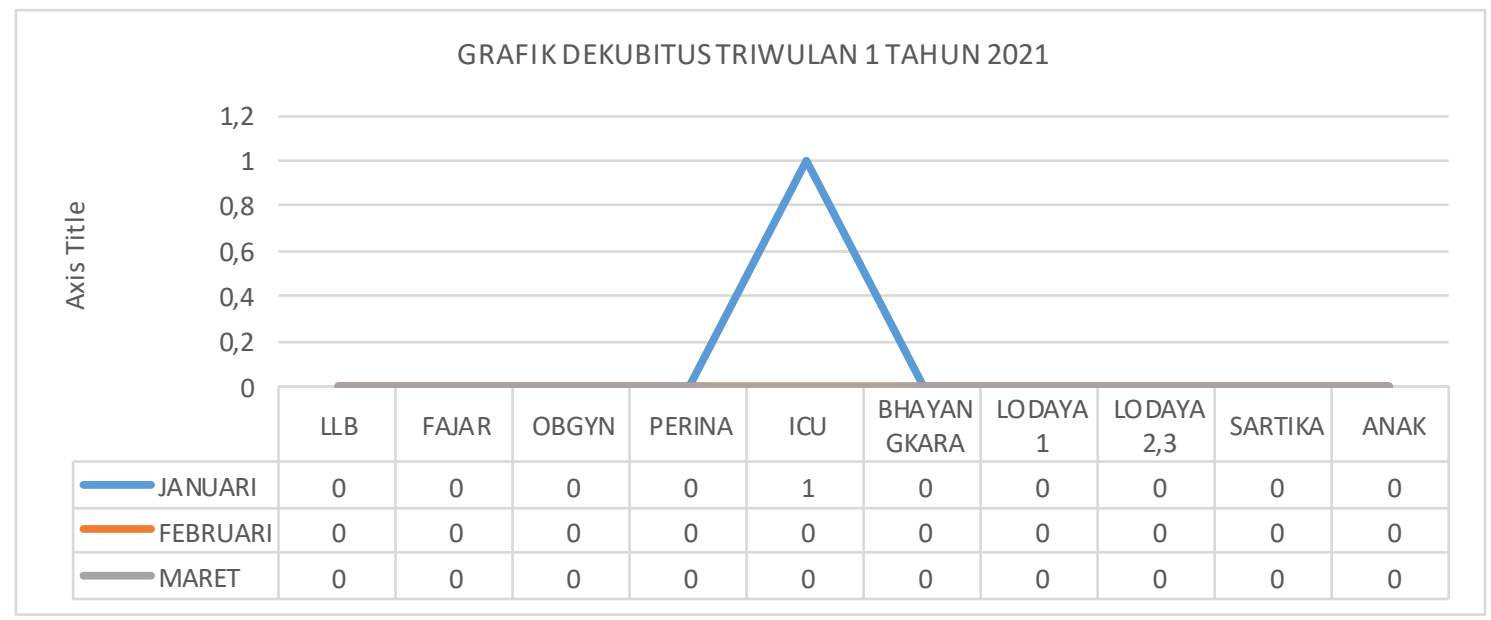

Dari grafik diatas menunjukan bahwa pada triwulan 1 di ruangan ICU terdapat kejadian dekubitus sebesar $1 \%$ terjadi pada bulan Januari 2021.

Beberapa rencana dan tindak lanjut yang telah dilaksanakan oleh Komite PPI, yaitu sebagai berikut:

1. Untuk pasien yang diharuskan tirah baring, bila kondisi pasien menungkinkan, tetap harus dilakukan mobilisasi minimal yaitu dengan mikamiki (miring kanan miring kiri) yang dinilai dapat mencegah dekubitus.
2. Bila kondisi pasien tidak memungkinkan, dapat di rekomendasikan penggunaan kasur dekubitus.

3. Mengusulkan untuk diadakan tambahan kasur dekubitus, mengingat beberapa pasien pindahan dari ruang HCU/ICU yang sebelumnya harus menggunakan kasur dekubitus, juga memerlukan kasur dekubitus di ruangan.

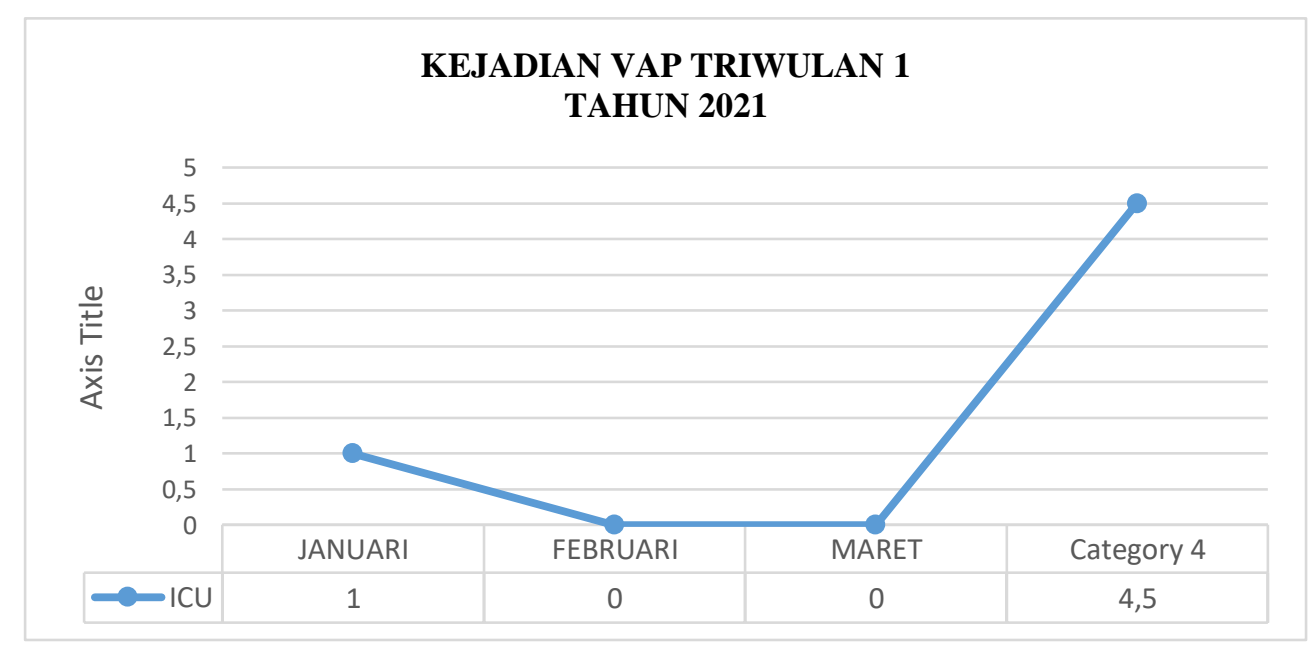

Dari grafik diatas menunjukan

Sartika Asih terjadi pada bulan Januari bahwa angka kejadian VAP di ruangan 2021 sebanyak $1 \%$.

ICU Rumah Sakit Bhayangkara TK II 
Analisis Program Pencegahan dan Pengendalian Infeksi dalam Pelaksanaan Surveilans Hai's di Rumah Sakit Bhayangkara Tk Ii Sartika Asih Bandung

Beberapa rencana dan tindak lanjut yang telah dilaksanakan oleh Komite PPI, yaitu sebagai berikut :
1. Memberikan Reward dan punishment untuk kepatuhan cuci tangan

2. Meningkatkan kepatuhan cuci tangan dengan cara memonitoring rutin.

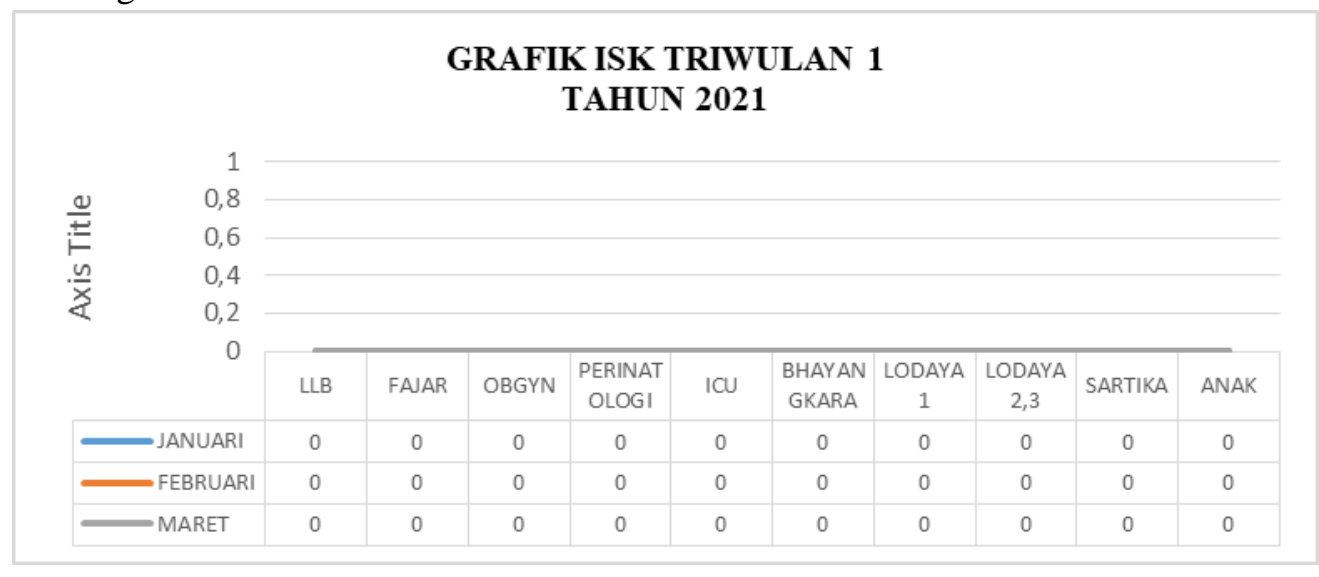

Dari grafik diatas menunjukan bahwa pada triwulan 1 yaitu bulan Januari-Maret 2021 tidak adanya kejadian ISK yang terjadi.

Beberapa rencana dan tindak lanjut yang telah dilaksanakan oleh Komite PPI, yaitu sebagai berikut:

1. Menerapkan bundle ISK dengan benar (pemasangan urine kateter digunakan hanya sesuai indikasi, kebersihan tangan, teknik insersi yang benar, pengambilan specimen, pemeliharaan kateter urine, dan lepaskan kateter jika sudah tidak diperlukan).

2. Memberikan Reward dan punishment untuk kepatuhan cuci tangan.

3. Melakukan Penerapan teknik aseptik pada saat prosedur dilaksanakan.

4. Meningkatkan kepatuhan cuci tangan dengan cara memonitoring rutin.

5. Mensosialisasikan kembali prosedur pemasangan kateter urine sesuai SPO.

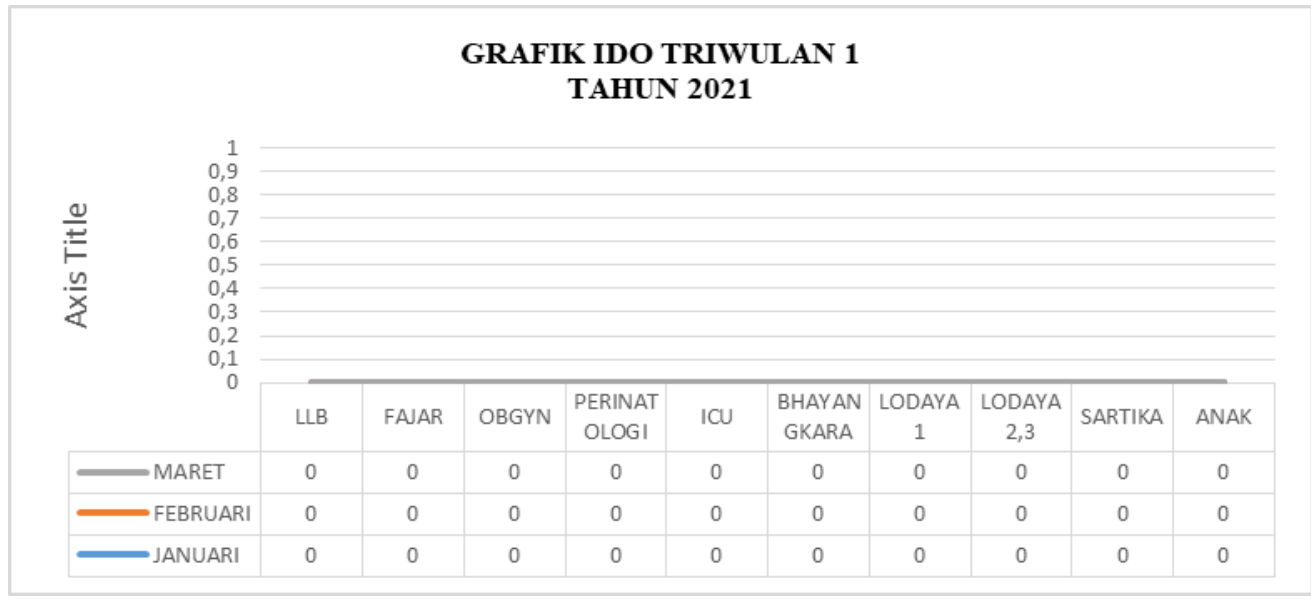

Dari Grafik diatas menunjukan bahwa tidak adanya angka kejadian IDO pada triwulan 1 bulan Januari-Maret tahun 2021.
Beberapa rencana dan tindak lanjut yang telah dilaksanakan oleh Komite PPI, yaitu sebagai berikut :

1. Menerapkan bundle IDO dengan benar (CATS). 
2. Memberikan Reward dan punishment untuk kepatuhan cuci tangan.

3. Meningkatkan kepatuhan cuci tangan dengan cara memonitoring rutin.

Dari hasil data penelitian yang telah dilakukan, maka infeksi nosokomial yang terjadi di Rumah Sakit Bhayangkara TK II Sartika Asih Bandung menunjukkan bahwa infeksi yang sering terjadi baik dari bulan januari, februari maupun maret yaitu infeksi Phlebitis, dan persentase menunjukkan bahwa infeksi Phlebitis ini telah sering terjadi.

Infeksi nosokomial menyebabkan 1,4 juta kematian setiap hari di seluruh dunia. Persentase infeksi nosokomial di rumah sakit dunia mencapai $9 \%$ (variasi $3-2 \%$ ) atau lebih 1,4 juta pasien rawat inap di rumah sakit seluruh dunia mendapatkan infeksi nosokomial.

Infeksi Phlebitis merupakan penyakit yang terjadi karena peradangan pada pembuluh darah vena yang disebabkan oleh kateter atau iritasi kimiawi zat aditif dan obatobatan yang diberikan secara intravena. Infeksi ini diperoleh dari rumah sakit dan infeksi ini tidak diderita pasien saat masuk ke rumah sakit melainkan setelah \pm 72 jam berada di tempat tersebut.

Pada program surveilans HAI's di Rumah Sakit Bhayangkara TK II Sartika Asih Bandung ini sudah sesuai dengan prosedur yang telah ditetapkan, namun dengan adanya infeksi nosokomial yang terjadi yaitu infeksi Phlebitis yang menyebabkan beberapa pasien terinfeksi maka komite PPI harus melakukan tindakan yang komprehensif sehingga akan dapat mengurangi atau meminimalkan infeksi yang akan terjadi di rumah sakit.

Infeksi nosokomial yang lain seperti infeksi decubitus, VAP, ISK dan IDO tidak sering terjadi di Rumah Sakit Bhayangkara TK II Sartika Asih Bandung, namun terjadi beberapa kali dalam triwulan 1 ini. Ini merupakan suatu hal yang baik karena tim komite PPI mampu mengurangi angka infeksi di rumah sakit. Kebijakan di rumah sakit dapat menjadi pemicu sebagai upaya terkendalinya infeksi ini serta SOP yang dijalankan dengan baik oleh semua SDM di rumah sakit.

\section{Kesimpulan}

Rumah sakit sebagai sarana penyedia jasa pelayanan kesehatan menjadi tolak ukur dalam upaya keberhasilan pemulihan keadaan pasien. Ini menjadi acuan bagi semua rumah sakit untuk dapat menyediakan pelayanan serta kualitas yang optimal guna memberikan jasa layanan kesehatan yang baik bagi pasien

Dalam program PPI pada pelaksanaan surveilans HAI's di Rumah Sakit Bhayangkara TK II Sartika Asih Bandung ini perlu mengupayakan strategi agar berkurangnya laju infeksi rumah sakit khususnya pada infeksi Phlebitis yang sudah terjadi paling banyak di rumah sakit ini. Namun pada infeksi yang lain juga seperti infeksi Dekubitus, VAP, ISK dan IDO juga diperlukan strategi agar dapat berkurang laju infeksi dan mengoptimalkan kinerja karyawan.

Berdasarkan data yang sudah diteliti maka Rumah Sakit Bhayangkara TK II Sartika Asih Bandung sudah menerapkan SOP dengan baik walaupun kurang optimal dalam hal penanganan infeksi terutama untuk infeksi Phlebitis. Prosedur dan kebijakan yang telah di tetapkan oleh rumah sakit pun sudah sesuai setidaknya untuk sedikit mengurangi laju infeksi yang terjadi di rumah sakit.

Di rumah sakit ini sudah melakukan pelaporan kejadian surveilans HAI's oleh Komite IPCN yang bertanggung jawab dalam proses ini meliputi pengumpulan data, analisa, evaluasi hingga pelaporan. Data yang di peroleh untuk kemudian diolah menjadi pelaporan hasil dari monitoring dari Komite IPCN. 
Analisis Program Pencegahan dan Pengendalian Infeksi dalam Pelaksanaan Surveilans Hai's di Rumah Sakit Bhayangkara Tk Ii Sartika Asih Bandung

\section{BIBLIOGRAFI}

Adhiwijaya, A. (2017). Pelaksanaan Pencegahan Dan Pengendalian Infeksi Dalam Peningkatan Mutu Pelayanan Di Rumah Sakit Umum Daerah Labuang Baji Makassar. Makassar: Tesis Universitas Hasanuddin. Google Scholar

Amirah, A., \& Safrizal Ahmaruddin, S. K. M. (2020). Konsep Dan Aplikasi Epidemiologi. Deepublish. Google Scholar

Ismainar, H. (2015). Keselamatan Pasien Di Rumah Sakit. Deepublish. Google Scholar

Madjid, T., \& Wibowo, A. (2019). Analisis Penerapan Program Pencegahan Dan Pengendalian Infeksi Di Ruang Rawat Inap Rsud Tebet Tahun 2017. Jurnal Administrasi Rumah Sakit Indonesia, 4(1). Google Scholar

Organization, W. H. (2018). Who Expert Consultation On Rabies: Third Report (Vol. 1012). World Health Organization. Google Scholar

Organization, W. H. (2019). Global Status Report On Alcohol And Health 2018. World Health Organization. Google Scholar

Purba, H. I. D., Girsang, V. I., \& Malay, U. S. (2018). Studi Kebijakan, Perencanaan Dan Pelaksanaan Keselamatan Dan Kesehatan Kerja Rumah Sakit (K3rs) Di
Rumah Sakit Umum (Rsu) Mitra Sejati Medan Tahun 2018. Jurnal Mutiara Kesehatan Masyarakat, 3(2), 113-124. Google Scholar

Ramayanti, R., Semiarty, R., \& Lestari, Y. (2019). Analisis Pelaksanaan Program Pencegahan Dan Pengendalian Infeksi Nosokomial Di Rsud Pasaman Barat (Standar Akreditasi Versi 2012). Jurnal Kesehatan Andalas, 8(3), 617-626. Google Scholar

Rikomah, S. E. (2017). Farmasi Rumah Sakit. Deepublish. Google Scholar

Salam, S. H. (2013). Gambaran Pengelolaan Limbah Medis Padat Di Rumah Sakit Dr. Tadjuddin Chalid Makassar 2013. Universitas Islam Negeri Alauddin Makassar. Google Scholar

Sutarto, S. T. T. (2017). Faktor Lingkungan, Perilaku Dan Penyakit Malaria. Agromedicine Unila, 4(1), 173-184. Google Scholar

Umar, T. (2012). Pencegahan Dan Pengendalian Infeksi Di Rumah Sakit Dan Fasilitas Kesehatan. Jakarta: Citra Medika. Google Scholar

Wardoyo, E. H., Wibowo, E. P., Jayantika, I. G., Sudiadnya, I. G. A. R., \& Armand, R. (2018). Surveilans Pasif Dan Aktif Kejadian Infeksi Terkait Pelayanan Kesehatan Di Rsud Provinsi Ntb, 2017. The Indonesian Journal of Infectious Diseases, 4(1). Google Scholar

\section{Copyright holder:}

Fitri Faridath, Ericka Aulia Rosyidah, Nurul Dwi Aryani (2021)

First publication right:

Jurnal Health Sains

This article is licensed under:

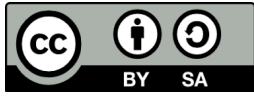

